\title{
Efektivitas Problem Based Learning Terhadap Kemampuan Berpikir Kreatif Mahasiswa Program Studi Tadris Matematika UIN Mataram
}

\author{
Fadrik Adi Fahrudin
}

Tadris Matematika, Universitas Islam Negeri Mataram, fadrik@uinmataram.ac.id

\section{INFO ARTIKEL}

Riwayat Artikel:

Diterima: 03-09-2017

Disetujui: 13-10-2017

\section{Kata Kunci: \\ Problem Based Learning; Creative Thinking Ability}

\begin{abstract}
ABSTRAK
Abstrak: Penelitian ini bertujuan untuk mengetahui efektivitas Problem Based Learning terhadap kemampuan berpikir kreatif mahasiswa Program Studi Tadris Matematika UIN Mataram. Pendekatan yang digunakan adalah kuantitatif dengan jenis penelitian eksperimen. Teknik pengambilan sampel dilakukan dengan cluster random sampling. Populasi penelitian ini adalah mahasiswa semester 3 sebanyak 108 mahasiswa dengan sampel kelas IIIA sebanyak 26 mahasiswa sebagai kelas eksperimen, dan kelas IIIB sebanyak 24 mahasiswa sebagai kelas kontrol. Hasil posttest menunjukkan bahwa nilai rata-rata kelas eksperimen sebesar 71,54 dan nilai ratarata kelas kontrol sebesar 63,35. Analisis uji-t diperoleh thitung $=2,55$ pada $d k=n_{1}+n_{2}-2$, $24+26-2=48$ dan $t_{\text {tabel }}=5 \%\left(\mathrm{t}_{0,05 ; 48}\right)=1,95$. Jadi pada $\mathrm{dk}=48$, thitung $>t_{\text {tabel }}$ yaitu $2,55>$ 1,95. Hal ini berarti bahwa $\mathrm{H}_{0}$ ditolak dan $\mathrm{H}_{a}$ diterima, dengan kata lain model pembelajaran Problem Based Learning efektif terhadap kemampuan berpikir kreatif mahasiswa Program Studi Tadris Matematika UIN Mataram.
\end{abstract}

\begin{abstract}
This research aims to determine the effectiveness of Problem Based Learning on the creative thinking ability of students of Mathematics Education Program of UIN Mataram. The approach used is quantitative with the type of experimental research. The sampling technique was done by cluster random sampling. The population of this research is student of 3rd grade of 108 students with class IIIA sample as much as 26 students as experiment class, and class IIIB as many as 24 students as control class. Post-test results show that the average grade of the experimental class is 71,54 and the average value of the control class is 63,35 . The $t$-test analysis is obtained $t$-count $=2,55$ at $d k=n_{1}+n_{2}-2,24+26-2=48$ and $t$-table $=5 \%\left(t_{0,05 ; 48}\right)=1,95$. So at $d k=48, t$-count $>t^{-}$ table $=2,55>1,95$. The conclusion is $H_{0}$ rejected and $H_{a}$ accepted, in other words Problem Based Learning is effective towards the creative thinking ability of students of Mathematics Education Program of UIN Mataram.
\end{abstract}

\section{A. LATAR BELAKANG}

Pendidikan adalah usaha sadar dan terencana untuk mewujudkan suasana belajar dan proses pembelajaran agar peserta didik secara aktif mengembangkan potensi dirinya untuk memiliki kekuatan spiritual keagamaan, pengendalian diri, kepribadian, kecerdasan, akhlak mulia, serta keterampilan yang diperlukan dirinya, masyarakat, bangsa dan negara. Saat ini Indonesia terus dihadapkan pada persoalan pendidikan yang kompleks, yaitu rendahnya mutu pendidikan pada setiap jenjang dan satuan pendidikan, tidak terkecuali Perguruan Tinggi. Berbagai upaya untuk meningkatkan mutu pendidikan tersebut juga terus dilakukan, mulai dari berbagai pelatihan untuk meningkatkan kualitas pendidik, penyempurnaan kurikulum secara periodik, perbaikan sarana dan prasarana pendidikan, sampai dengan peningkatan mutu manajemen di lembaga penyelenggara pendidikan. Namun, indikator kearah mutu pendidikan belum menunjukkan peningkatan yang signifikan.

Persoalan rendahnya mutu pendidikan dapat bersumber pada proses pembelajaran yang dilakukan. Fakta-fakta yang terjadi di lapangan khususnya dalam pembelajaran ilmu matematika, dosen menyampaikan materi dengan menggunakan salah satu metode yang biasa digunakan yaitu metode ceramah.

"Ceramah adalah metode yang boleh dikatakan metode tradisional, karena sejak dulu metode ini di pergunakan sebagai alat komunikasi lisan antara guru dan siswa. Dalam penerapan proses belajar mengajar lebih berpusat pada guru, siswa hanya 
mendengarkan, menulis dan menghafal materi yang diajarkan dan mengerjakan soal secara individu sehingga proses belajar mengajar bersifat satu arah.

Selama ini dalam menyampaikan materi perkuliahan, dosen lebih banyak menerapkan metode ceramah yang sifatnya monoton dan kurang variatif. Peran dosen lebih dominan dalam proses pembelajaran yang mengakibatkan partisipasi, aktivitas dan motivasi siswa masih terlihat kurang. Sistem pembelajaran seperti ini cenderung hanya mengejar materi sesuai dengan target kurikulum. Akibatnya mahasiswa menjadi kurang aktif dan hanya menerima apa yang diberikan oleh dosen. Hal ini berdampak pada perilaku mahasiswa yang kurang percaya diri, baik dalam bertanya, menyampaikan ide atau pendapat maupun dalam proses pemecahan masalah yang dihadapi, yang pada akhirnya bermuara pada rendahnya hasil capaian belajar mahasiswa.

Dalam perkembangan peradaban modern, matematika memegang peranan penting karena dengan bantuan matematika semua ilmu pengetahuan menjadi lebih sempurna. Oleh karena itu pelajaran matematika diajarkan mulai dari pendidikan dasar, menengah bahkan sampai pada perguruan tinggi. Selain itu pelajaran matematika merupakan salah satu pelajaran yang mendapat prioritas untuk dikembangkan, karena matematika merupakan pelayan bagi ilmu lain. Permasalahan kehidupan baik lahir maupun batin dalam berbagai aspek misalnya sosial, budaya, ekonomi, politik dan mental yang semakin hari semakin rumit saja. Hal ini disebabkan kurangnya minat dan motivasi terhadap matematika.

Melihat hal ini maka seorang dosen matematika dituntut untuk lebih kreatif dalam memilih strategi pembelajaran yang sesuai dengan materi pembelajaran yang akan disajikan kepada mahasiswa. Pada kenyataannya dalam pembelajaran matematika masih terlihat bahwa dosen mengembangkan pembelajaran dengan mendominasi kelas, sehingga mahasiswa tidak sepenuhnya berperan aktif, hanya dapat duduk mendengar, mencatat, menghafal dan bekerja secara individu di tempat duduk masingmasing. Penyajian materi matematika semata-mata berorientasi pada materi yang tercantum dalam kurikulum atau buku teks.

Rendahnya mutu pendidikan merupakan permasalahan utama dalam pengelolaan pendidikan saat ini. Salah satu upaya meningkatkan mutu pendidikan adalah dengan cara perbaikan proses balajar mengajar. Berbagai konsep dan wawasan baru tentang proses belajar mengajar telah muncul seiring dengan perkembangan ilmu pengetahuan yang semakin pesat. Dalam pembelajaran ilmu matematika pada jenjang Perguruan Tinggi, mahasiswa tidak hanya dituntut aktif dalam proses pembelajaran tersebut karena ilmu matematika merupakan salah satu dalam pemerolehan informasi pengetahuan dalam kelas, melainkan juga luar kelas, karena matematika bidang ilmu yang mendahulukan intelektualitas tinggi dan bukan sekedar bidang ilmu yang bersifat informatif dan teoritis saja. Oleh karena itu, perlu diterapkan suatu model pembelajaran yang efektif dalam mengembangkan kemampuan mahasiswa, yaitu melalui Problem Based Learning (PBL).

Pembelajaran berbasis masalah bermaksud untuk memberikan ruang gerak berpikir yang bebas kepada mahasiswa untuk mencari konsep dan menyelesaikan masalah yang terkait dengan materi yang disampaikan oleh guru. Karena pada dasarnya ilmu matematika bertujuan agar mahasiswa memahami konsep-konsep matematika dengan kehidupan sehari-hari. Memiliki keterampilan tentang alam sekitar untuk mengembangkan pengetahuan tentang proses alam sekitar,mampu menerapkan berbagi konsep matematika untuk menjelaskan gejala alam dan mampu menggunakan teknologi sederhana untuk memecahkan masalah yang ditemukan pada kehidupan sehari-hari.

Dengan menggunakan pendekatan PBL mahasiswa tidak hanya sekedar menerima informasi dari guru saja, karena dalam hal ini guru sebagai motivator dan fasilitator yang mengarahkan siswa agar terlibat secara aktif dalam seluruh proses pembelajaran dengan diawali pada masalah yang berkaitan dengan konsep yang dipelajari. Karateristik PBL lebih mengacu pada aliran pendidikan kontruktivmisme, dimana belajar merupakan proses aktif dari pembelajaran untuk membangun pengetahuan. Proses aktif yang dimaksud tidak hanya bersifat secara mental tetapi juga secara fisik. Artinya, melalui aktivitas secara fisik pengetahuan siswa secara aktif dibangun berdasarkan proses asimilasi pengalaman atau bahan yang dipelajari dengan pengetahuan yang telah dimiliki dan ini berlangsung secara mental.

Keterampilan berpikir memiliki peranan penting dalam suatu proses pembelajaran, yang salah satunya adalah berpikir kreatif. Pengembangan berpikir secara kreatif sebenarnya telah terlihat pada pendekatan konstruktivistik dalam pembelajaran. Disini mahasiswa lebih berperan aktif dan kreatif dalam mengkonstruksi pengalaman pembelajaran. Kemampuan berpikir kreatif merupakan salah satu kompetensi penting sebagai bagian dari kecakapan hidup (life skills) yang menjadi salah satu tujuan pendidikan nasional yang secara eksplisit tercantum dalam Undang-Undang Republik Indonesia Nomor 20 Tahun 2003 tentang Sistem Pendidikan Nasional bahwa pendidikan bertujuan untuk mengembangkan potensi peserta didik agar menjadi manusia yang beriman dan bertakwa kepada Tuhan Yang Maha Esa, 
berakhlak mulia, sehat, berilmu, cakap, kreatif, mandiri, dan menjadi warga negara yang demokratis serta bertanggung jawab. Oleh karena itu, berdasarkan uraian di atas peneliti mengadakan penelitian dengan judul "Efektivitas Problem Based Learning terhadap Kemampuan Berpikir Kreatif Mahasiswa Program Studi Tadris Matematika UIN Mataram".

\section{B. METODE PENELITIAN}

Penelitian ini menggunakan pendekatan kuantitatif berjenis penelitian eksperimen. Penelitian didesain dengan memberikan perlakuan kepada kelas eksperimen dan kelas kontrol yang masingmasing akan diberikan pre-test dan post-test secara bersamaan. Pada penelitian ini kelas eksperimen diberikan perlakuan (X), yaitu menggunakan Problem Based Learning, sedangkan kelas kontrol tidak diberi perlakuan atau tetap menggunakan metode ceramah.

TABEL 1

DESAIN PENELITIAN

\begin{tabular}{|l|c|c|c|}
\hline \multicolumn{1}{|c|}{ Kelas } & Pre-Test & Perlakuan & Post-Test \\
\hline Eksperimen & $\mathrm{O}_{1}$ & $\mathrm{X}$ & $\mathrm{O}_{2}$ \\
\hline Kontrol & $\mathrm{O}_{3}$ & - & $\mathrm{O}_{4}$ \\
\hline
\end{tabular}

Populasi dalam penelitian ini adalah mahasiswa semester 3 Program Studi Tadris Matematika sebanyak 108 mahasiswa. Sampel terdiri dari 26 mahasiswa kelas IIIA sebagai kelas eksperimen, dan 24 mahasiswa dari kelas IIIB sebagai kelas kontrol, sedangkan instrumen yang digunakan oleh peneliti terdiri dari:

a. Tes tertulis

Digunakan untuk mengukur tingkat kemampuan berpikir kreatif mahasiswa dalam pembelajaran matematika. Tes tertulis yang diberikan kepada siswa, meliputi pretest dan post-test baik untuk kelas eksperimen maupun kelas kontrol yang bertujuan untuk mengetahui kemampuan berpikir kreatif mahasiswa sesudah diberikan perlakuan.

b. Dokumentasi

Dokumentasi digunakan untuk memperkuat data yang diperoleh dari hasil tes tertulis. Data yang diperoleh dari dokumantasi berupa SAP, hasil unjuk kerja mahasiswa dan foto yang memberikan gambaran pelaksanaan pembelajaran.

Analisa data dilakukan melalui:

a. Uji Normalitas

Uji normalitas dilakukan untuk mengetahui sejauh mana normalitas data yang akan dianalisis. Apabila tidak normal, maka data diolah menggunakan statistik non parametrik, misalnya uji chi kuadrat $\left(x^{2}\right)$. Dalam proses uji normalitas ini peneliti akan memanfaatkan software program SPSS 15. b. Uji Homogenitas

Berdasarkan jumlah mahasiswa yang terdapat di kelas eksperimen dan kelas kontrol, maka diketahui bahwa $\mathrm{n}_{1} \neq \mathrm{n}_{2}$, tetapi peneliti tidak bisa mengetahui apakah data hasil analisis menunjukan varian yang homogen $\left(\sigma^{2}=\sigma^{2}\right)$ atau varian yang tidak homogen $\left(\sigma^{2} \neq \sigma^{2}\right)$. Untuk mengetahui suatu varian homogen atau tidak, maka peneliti melakukan uji homogenitas variannya terlebih dahulu dengan menggunakan uji f.

$$
f=\frac{\text { VarianTerbesar }}{\text { VarianTerkecil }}
$$

Jika:

- $\mathrm{f}_{\text {hitung }}<\mathrm{f}_{\text {tabel }}$ maka varian kedua kelompok tersebut adalah Homogen

- $f_{\text {hitung }} \geq f_{\text {tabel }}$ maka varian kedua kelompok tersebut tidak Homogen

Untuk mengetahui kelompok mana yang memiliki nilai varian terbesar dan terkecil, peneliti menggunakan rumus varians $\left(\mathrm{s}^{2}\right)$.

$$
s^{2}=\frac{n \sum_{i=1}^{n} x_{i}^{2}-\left(\sum_{i=1}^{n} x_{i}\right)^{2}}{n(n-1)}
$$

Setelah mengetahui nilai varians masingmasing kelompok, peneliti bisa langsung menggunakan rumus t yang harus dipakai.

Langkah selanjutnya adalah menganalisis data dengan mengunakan uji $t$ yang telah ditentukan. Terdapat beberapa rumus t-test yang digunakan untuk pengujian,

1. Bila jumlah anggota sampel $\mathrm{n}_{1}=\mathrm{n}_{2}$, dan varian homogen $\left(\sigma^{2}=\sigma^{2}\right)$ maka dapat digunakan rumus t-test baik untuk sparated, maupun pooled varian, (Rumus 3 dan 4). Untuk melihat harga $t$ tabel digunakan derajat kebebasan (dk) $d k=n_{1}+n_{2}-2$.

2. Bila $\mathrm{n}_{1} \neq \mathrm{n}_{2}$, varian homogen $\left(\sigma^{2}=\sigma^{2}\right)$ maka dapat digunakan rumus t-tes dengan pooled varian. (rumus 4). $d k=n_{1}+n_{2}-2$.

3. Bila $n_{1}=n_{2}$, varian tidak homogen $\left(\sigma^{2} \neq \sigma^{2}\right)$ dapat digunakan rumus 3 dan 4; $d k=n_{1}-1 \mathrm{dk}=\mathrm{n}_{1}-1$ atau $n_{2}-1$. Jadi $\mathrm{dk}$ bukan $d k=n_{1}+n_{2}-2$.

4. Bila $\mathrm{n}_{1} \neq \mathrm{n}_{2}$, varian tidak homogen $\left(\sigma^{2} \neq \sigma^{2}\right)$. Untuk ini digunakan t-tes dengan sparated varian, rumus 3 . harga t sebagai pengganti t-tabel dihitung dari selisih harga $t$ tebel dengan $\quad d k=n_{1}-1 \quad$ dan $\quad d k=n_{2}-1$ ) dibagi dua, dan kemudian ditambahkan dengan harga t yang terkecil. 


$$
\begin{aligned}
& t=\frac{\overline{X_{1}}-\overline{X_{2}}}{\sqrt{\frac{s_{1}^{2}}{n_{1}}+\frac{s_{2}^{2}}{n_{2}}}} \\
& t=\frac{\overline{X_{1}}-\overline{X_{2}}}{\sqrt{\frac{\left(n_{1}-1\right) s_{1}^{2}+\left(n_{2}-1\right) s_{2}^{2}}{n_{1}+n_{2}-2}\left(\frac{1}{n 1}+\frac{1}{n_{2}}\right)}}
\end{aligned}
$$

Kepekaan berfikir kreatif dapat diukur dengan indikator-indikator yang telah ditentukan para ahli, yaitu:

a. Fluency (kelancaran), yaitu menghasilkan banyak ide dalam berbagai kategori/bidang.

b. Originality (keaslian), yaitu memiliki ide-ide baru untuk memecahkan persoalan.

c. Elaboration (penguraian), yaitu kemampuan memecahkan masalah secara detail (Herdian, 2010)

Menurut model Williams (dalam Munandar) perilaku siswa yang termasuk dalam keterampilan kognitif kreatif sebagai berikut.

TABEL 2

\begin{tabular}{|c|c|}
\hline Pengertian & Perilaku \\
\hline $\begin{array}{l}\text { Berfikir Lancar } \\
\text { (fluency) } \\
\text { 1. Mencetuskan } \\
\text { banyak gagasan, } \\
\text { jawaban, } \\
\text { penyelesaian masalah } \\
\text { atau jawaban }\end{array}$ & $\begin{array}{l}\text { a. Mengajukan banyak } \\
\text { pertanyaan } \\
\text { b. Menjawab dengan sejumlah } \\
\text { jawaban jika ada }\end{array}$ \\
\hline $\begin{array}{l}\text { 2. Memberikan } \\
\text { banyak cara atau } \\
\text { saran untuk } \\
\text { melakukan berbagai } \\
\text { hal }\end{array}$ & $\begin{array}{l}\text { c. Mempunyai banyak gagasan } \\
\text { mengenai suatu masalah }\end{array}$ \\
\hline \multirow{4}{*}{$\begin{array}{l}\text { 3. Selalu memikirkan } \\
\text { lebih dari satu } \\
\text { jawaban }\end{array}$} & d. Lancar mengungkapkan \\
\hline & gagasan-gagasannya \\
\hline & $\begin{array}{l}\text { e. Bekerja lebih cepat dan } \\
\text { melakukan lebih banyak dari } \\
\text { orang lain }\end{array}$ \\
\hline & $\begin{array}{l}\text { f. Dapat dengan cepat melihat } \\
\text { kesalahan dan kelemahan dari } \\
\text { suatu objek atau situasi }\end{array}$ \\
\hline $\begin{array}{l}\text { Berfikir Luwes } \\
\text { (flexibility) }\end{array}$ & $\begin{array}{l}\text { a. Memberikan aneka ragam } \\
\text { penggunaan yang tak lazim } \\
\text { terhadap suatu objek. }\end{array}$ \\
\hline $\begin{array}{l}\text { 1. Menghasilkan } \\
\text { gagasan, jawaban, } \\
\text { atau pertanyaan yang } \\
\text { bervariasi }\end{array}$ & $\begin{array}{l}\text { b. Memberikan bermacam- } \\
\text { macam penafsiran terhadap } \\
\text { suatu gambar, cerita atau } \\
\text { masalah }\end{array}$ \\
\hline $\begin{array}{l}\text { 2. Dapat melihat } \\
\text { suatu masalah dari } \\
\text { sudut pandang yang } \\
\text { berbeda }\end{array}$ & $\begin{array}{l}\text { c. Menerapkan suatu konsep } \\
\text { atau asas dengan cara yang } \\
\text { berbeda-beda }\end{array}$ \\
\hline $\begin{array}{l}\text { 3. Mencari banyak } \\
\text { alternatif atau arah } \\
\text { yang berbeda }\end{array}$ & $\begin{array}{l}\text { d. Memberikan pertimbangan } \\
\text { terhadap situasi yang berbeda } \\
\text { dari yang diberikan orang lain }\end{array}$ \\
\hline
\end{tabular}

INDIKATOR BERPIKIR KREATIF

\begin{tabular}{|c|c|}
\hline \multirow[t]{4}{*}{$\begin{array}{l}\text { 4. Mampu mengubah } \\
\text { cara pendekatan atau } \\
\text { pemikiran }\end{array}$} & $\begin{array}{l}\text { e. Dalam membahas, } \\
\text { mendiskusikan suatu situasi } \\
\text { selalu mempunyai posisi yang } \\
\text { bertentangan dengan } \\
\text { mayoritas kelompok }\end{array}$ \\
\hline & $\begin{array}{l}\text { f. Jika diberikan suatu masalah } \\
\text { biasanya memikirkan } \\
\text { bermacam-macam cara untuk } \\
\text { menyelesaikannya }\end{array}$ \\
\hline & $\begin{array}{l}\text { g. Menggolongkan hal-hal } \\
\text { menurut pembagian (kategori) } \\
\text { yang berbeda-beda }\end{array}$ \\
\hline & $\begin{array}{l}\text { h. Mampu mengubah arah } \\
\text { berfikir secara spontan }\end{array}$ \\
\hline $\begin{array}{l}\text { Berfikir Orisinil } \\
\text { (Originality) }\end{array}$ & $\begin{array}{l}\text { a. Memikirkan masalah- } \\
\text { masalah atau hal yang tidak } \\
\text { terpikirkan orang lain }\end{array}$ \\
\hline $\begin{array}{l}\text { 1. Mampu melahirkan } \\
\text { ungkapan yang baru } \\
\text { dan unik }\end{array}$ & $\begin{array}{l}\text { b. Mempertanyakan cara-cara } \\
\text { yang lama dan berusaha } \\
\text { memikirkan cara-cara yang } \\
\text { baru }\end{array}$ \\
\hline $\begin{array}{l}\text { 2. Memikirkan cara- } \\
\text { cara yang tak lazim } \\
\text { untuk } \\
\text { mengungkapkan diri }\end{array}$ & $\begin{array}{l}\text { c. Memilih asimetri dalam } \\
\text { mengambarkan atau membuat } \\
\text { desain }\end{array}$ \\
\hline $\begin{array}{l}\text { 3. Mampu membuat } \\
\text { kombinasi-kombinasi } \\
\text { yang tak lazim dari } \\
\text { bagian-bagian atau } \\
\text { unsur-unsur }\end{array}$ & $\begin{array}{l}\text { d. Memilih cara berpikir lain } \\
\text { dari pada yang lain }\end{array}$ \\
\hline
\end{tabular}

\begin{tabular}{|c|c|}
\hline & $\begin{array}{l}\text { e. Mencari pendekatan yang } \\
\text { baru dari yang klise }\end{array}$ \\
\hline & $\begin{array}{l}\text { f. Setelah membaca atau } \\
\text { mendengar gagasan-gagasan, } \\
\text { bekerja untuk menyelesaikan } \\
\text { yang baru }\end{array}$ \\
\hline & $\begin{array}{l}\text { g. Lebih senang mensintesa } \\
\text { dari pada menganalisis sesuatu }\end{array}$ \\
\hline $\begin{array}{l}\text { Berpikir Elaboratif } \\
\text { (Elaboration) }\end{array}$ & $\begin{array}{l}\text { a. Mencari arti yang lebih } \\
\text { mendalam terhadap jawaban } \\
\text { atau pemecahan masalah } \\
\text { dengan melakukan langkah- } \\
\text { langkah yang terperinci }\end{array}$ \\
\hline $\begin{array}{l}\text { 1. Mampu } \\
\text { memperkaya dan } \\
\text { mengembangkan } \\
\text { suatu gagasan atau } \\
\text { produk }\end{array}$ & $\begin{array}{l}\text { b. Mengembangkan atau } \\
\text { memperkaya gagasan orang } \\
\text { lain }\end{array}$ \\
\hline \multirow[t]{2}{*}{$\begin{array}{l}\text { 2. Menambah atau } \\
\text { merinci detail-detail } \\
\text { dari suatu objek, } \\
\text { gagasan atau situasi } \\
\text { sehingga menjadi } \\
\text { lebih menarik }\end{array}$} & $\begin{array}{l}\text { c. Mencoba atau menguji } \\
\text { detail-detail untuk melihat } \\
\text { arah yang akan ditempuh. }\end{array}$ \\
\hline & $\begin{array}{l}\text { d. Mempunyai rasa keindahan } \\
\text { yang kuat, sehingga tidak puas } \\
\text { dengan penampilan yang } \\
\text { kosong atau sederhana }\end{array}$ \\
\hline
\end{tabular}

Pada penelitian ini yang akan dijadikan tolak ukur kemampuan berfikir kreatif adalah berfikir lancar, kemampuan berfikir luwes, kemampuan 
berfikir originalitas, dan kemampuan berfikir elaboratif. Adapun kriteria penskoran yang digunakan dalam penelitian ini adalah skor rubrik yang dimodifikasi dari Bosch (Febrianita, 2010).

TABEL 3

PEDOMAN PENSKORAN

KEMAMPUAN BERFIKIR KREATIF MATEMATIKA

\begin{tabular}{|c|c|c|}
\hline $\begin{array}{c}\text { Aspek yang } \\
\text { Diukur } \\
\end{array}$ & $\begin{array}{c}\text { Respon Mahasiswa } \\
\text { terhadap Soal/ Masalah }\end{array}$ & Skor \\
\hline \multirow{5}{*}{ Elaborasi } & $\begin{array}{l}\text { Tidak } \\
\text { menjawab/memberikan } \\
\text { jawaban yang salah }\end{array}$ & 0 \\
\hline & $\begin{array}{l}\text { Terdapat kekeliruan dalam } \\
\text { memperluas situasi tanpa } \\
\text { disertai perincian }\end{array}$ & 1 \\
\hline & $\begin{array}{l}\text { Terdapat kekeliruan dalam } \\
\text { memperluas situasi dan } \\
\text { disertai perincian yang } \\
\text { kurang detil }\end{array}$ & 2 \\
\hline & $\begin{array}{l}\text { Memperluas situasi dengan } \\
\text { benar dan merincinya kurang } \\
\text { detil }\end{array}$ & 3 \\
\hline & $\begin{array}{l}\text { Memperluas situasi dengan } \\
\text { benar dan memerincinya } \\
\text { secara detil }\end{array}$ & 4 \\
\hline \multirow{5}{*}{$\begin{array}{l}\text { Kelancaran } \\
\text { (Fluency) }\end{array}$} & $\begin{array}{l}\text { Tidak } \\
\text { menjawab/memberikan ide } \\
\text { yang tidak relevan untuk } \\
\text { pemecahan masalah }\end{array}$ & 0 \\
\hline & $\begin{array}{l}\text { Memberikan sebuah idea } \\
\text { yang relevan dengan } \\
\text { pemecahan masalah tetapi } \\
\text { pengungkapannya kurang } \\
\text { jelas }\end{array}$ & 1 \\
\hline & $\begin{array}{l}\text { Memberikan sebuah ide yang } \\
\text { relevan dengan pemecahan } \\
\text { masalah dan } \\
\text { pengungkapannya lengkap } \\
\text { serta jelas }\end{array}$ & 2 \\
\hline & $\begin{array}{l}\text { Memberkan lebih dari satu } \\
\text { ide yang relevan pemecahan } \\
\text { masalah tetapi } \\
\text { pengungkapannya kurang } \\
\text { jelas }\end{array}$ & 3 \\
\hline & $\begin{array}{l}\text { Memberikan lebih dari satu } \\
\text { ide yang relevan dengan } \\
\text { pemecahan masalah dan } \\
\text { pengungkapannya lengkap } \\
\text { serta jelas }\end{array}$ & 4 \\
\hline \multirow{3}{*}{$\begin{array}{l}\text { Keluwesan } \\
\text { (Flexibility) }\end{array}$} & $\begin{array}{l}\text { Tidak } \\
\text { menjawab/memberikan ide } \\
\text { yang tidak relevan untuk } \\
\text { pemecahan masalah }\end{array}$ & 0 \\
\hline & $\begin{array}{l}\text { Memberikan jawaban hanya } \\
\text { satu cara dan terdapat } \\
\text { kekeliruan dalam proses } \\
\text { perhitungan sehingga } \\
\text { hasilnya salah }\end{array}$ & 1 \\
\hline & $\begin{array}{l}\text { Memberikan jawaban dengan } \\
\text { satu cara, proses perhitungan } \\
\text { dan hasilnya benar }\end{array}$ & 2 \\
\hline
\end{tabular}

Memberikan jawaban lebih

dari satu cara (beragam)

tetapi hasilnya ada yang

salah karena terdapat

kekeliruan dalam proses

perhitungan

Memberikan jawaban lebih

4

dari satu cara (beragam),

proses perhitungan dan

hasilnya benar

Tidak

menjawab/memberikan

jawaban yang salah

Memberikan jawaban dengan

caranya sendiri tetapi tidak

dapat dipahami

Memberikan jawaban dengan 2

caranya sendiri, proses

Keaslian perhitungan sudah terarah

(Originality) tetapi tidak selesai

Memberikan jawaban dengan 3

caranya sendiri tetapi

terdapat kekeliruan dalam

proses perhitungan sehingga

hasilnya salah

Memberikan jawaban dengan

4

caranya sendiri dan proses

perhitungan serta hasilnya

benar

\section{HASIL DAN PEMBAHASAN}

Dalam penelitian kuantitatif, analisis data merupakan kegiatan yang dilakukan peneliti setelah semua data terkumpul. Peneliti melakukan pengujian terhadap hipotesis yang telah diajukan sebelumnya, yaitu: Problem Based Learning efektif terhadap kemampuan berpikir kreatif mahasiswa. Langkahlangkah yang dilakukan oleh peneliti, yaitu:

1. Melakukan Uji Normalitas

Analisis data menggunakan uji t mensyaratkan data harus berdistribusi normal karena uji $t$ merupakan bagian dari statistik inferensial jenis parametrik. Data dalam penelitian ini diuji kenormalannya menggunakan Software SPSS.15 dengan hasil sebagai berikut.

TABLE 4

HASIL HITUNG UJI ONE-SAMPLE KOLMOGROVSMIRNOV TEST

\begin{tabular}{|ll|c|c|}
\hline & & kontrol & eksperimen \\
\hline N & & 24 & 26 \\
& Mean & 63.35 & 71.54 \\
Most Extreme & Std. Deviation & 11.274 & 11.415 \\
Differences & Absolute & .098 & .155 \\
& Positive & .098 & .106 \\
Kolmogorov-Smirnov Z & Negative & -.081 & -.154 \\
Asymp. Sig. (2-tailed) & & .561 & .921 \\
\end{tabular}

a. Test distribution is Normal

b. Calculated from data 
Dasar pengambilan keputusan adalah berdasarkan probabilitas:

Jika nilai probabilitas $\leq 0,05$ maka $\mathrm{H}_{\mathrm{o}}$ diterima Jika nilai probabilitas $>0,05$ maka $\mathrm{H}_{\mathrm{o}}$ ditolak Keputusan:

a) Kontrol : Terlihat bahwa pada kolom signifikan (Asymp. Sig (2-tailed)) adalah 0,916 atau probabilitas lebih dari 0,05 maka $\mathrm{H}_{\mathrm{o}}$ ditolak dan $\mathrm{H}_{\mathrm{a}}$ diterima yang berarti populasi berdistribusi normal.

b) Eksperimen : Terlihat bahwa pada kolom signifikan (Asymp. Sig (2-tailed)) adalah 0,360 atau probabilitas lebih dari 0,05 maka $\mathrm{H}_{\mathrm{o}}$ ditolak dan $\mathrm{H}_{\mathrm{a}}$ diterima yang berarti populasi berdistribusi normal.

Kesimpulan uji normalitas data menggunakan SPSS.15 dengan tabel one-sample kolmogrovsmirnov test menghasilkan kesimpulan bahwa data yang akan diuji ini merupakan data yang berdistribusi Normal.

2. Melakukan Uji Homogenitas

Rumus untuk penentuan uji homogenitas dari beberapa kelompok data adalah dengan membandingkan varians terbesar dengan varian terkecil.

$$
\begin{aligned}
& F=\frac{\text { var ians terbesar }}{\text { var ians terkecil }} \\
& F=\frac{\text { var ianseksperimen }}{\text { var iankontrol }}=\frac{130,302}{127,340}=1,02
\end{aligned}
$$

TABEL 5

HASIL HITUNG UJI VARIANSI DATA POST TES

\begin{tabular}{|c|c|}
\hline \multicolumn{2}{|c|}{ Hasil Variansi Data Post Test } \\
\hline Kelas eksperimen & 130,302 \\
\hline Kelas kontrol & 127,340 \\
\hline
\end{tabular}

$\mathrm{F}_{\text {table }}$ dengan keterangan $\mathrm{dk}$ pembilang adalah jumlah data varian terbesar dikurangi $1 \mathrm{dan} d \mathrm{dk}$ penyebut adalah jumlah data varian terkecil dikurangi 1 dengan taraf signifikansi 5\%. Diperoleh $\mathrm{dk}$ pembilang 26-1=25 dan $\mathrm{dk}$ penyebut $24-1=23$. Hasil $F_{\text {table }}$ adalah 1,75. Karena $\mathrm{F}_{\text {hitung }}$ lebih kecil dari $\mathrm{F}_{\text {tabel }}\left(\mathrm{F}_{\text {hitung }}<\mathrm{F}_{\text {tabel }}\right)$, yaitu $1,02<1,75$, berdasarkan kriteria yang ditentukan maka data dikatakan Homogen. Karena data berdistribusi normal dan homogen, maka analisis dengan parametris dapat dilanjutkan, pada penelitian ini peneliti menggunakan uji t sampel berpasangan/related.

3. Merumuskan Hipotesis

a) Hipotesis Penelitian

$\mathrm{H}_{0}$ : Problem Based Learning (PBL) tidak efektif terhadap kemampuan berpikir kreatif mahasiswa Program Studi Tadris Matematika UIN Mataram.
$\mathrm{H}_{\mathrm{a}}$ : Problem Based Learning (PBL) efektif terhadap kemampuan berpikir kreatif mahasiswa Program Studi Tadris Matematika UIN Mataram

Pengambilan keputusan didasarkan pada:

Jika $\mathrm{t}_{\text {hitung }} \leq \mathrm{t}_{\text {tabel, }}$, maka $\mathrm{H}_{0}$ diterima, dan

Jika $\mathrm{t}_{\text {hitung }}>\mathrm{t}_{\text {tabel, }}$ maka $\mathrm{H}_{0}$ ditolak

4. Uji t Pooled Varian

TABEL 6

NILAI RATA-RATA, JUMLAH DATA DAN VARIANSI

\begin{tabular}{lcc}
\hline Parameter & Kelas Kontrol & Kelas Eksperimen \\
\hline Rata-rata & 63,35 & 71,54 \\
\hline Jumlah data & 24 & 26 \\
Variansi & 127,340 & 130,302 \\
\hline
\end{tabular}

$$
t=\frac{\overline{X_{1}}-\overline{X_{2}}}{\sqrt{\frac{\left(n_{1}-1\right) s_{1}^{2}+\left(n_{2}-1\right) s_{2}^{2}}{n_{1}+n_{2}-2}\left(\frac{1}{n 1}+\frac{1}{n_{2}}\right)}}
$$

Ket:

$\overline{X_{1}}=$ rata-rata kelas kontrol

$\overline{X_{2}}=$ rata-rata kelas eksperimen

$n_{1}=$ jumlah sampel kelas kontrol

$n_{2}=$ jumlah sampel kelas eksperimen

$s_{1}^{2}=$ Variansi kelas kontrol

$s_{2}^{2}=$ Variansi kelas eksperimen

$$
\begin{aligned}
& t=\frac{63,35-71,54}{\sqrt{\frac{(24-1) 127,34+(26-1) 130,302}{24+26-2}\left(\frac{1}{24}+\frac{1}{26}\right)}} \\
& t=\frac{-8,19}{\sqrt{\frac{(23) 127,34+(25) 130,302}{48}(0,042+0,038)}} \\
& t=\frac{-8,19}{\sqrt{\frac{2928,28+3257,55}{48}(0,08)}} \\
& t=\frac{-8,19}{\sqrt{\frac{6185,83}{48}(0,08)}} \\
& t=\frac{-8,19}{\sqrt{10,309}} \\
& t=\frac{-8,19}{3,21} \\
& t=-2,55
\end{aligned}
$$

Dari penghitungan di atas diperoleh bahwa $t_{\text {hitung }}$ $=2,55$. Hasil $t_{\text {hitung }}$ ini dibandingkan dengan $t_{\text {tabel }}$ dengan taraf signifikansi 5\% dengan ketentuan $\mathrm{dk}=$ $n_{1}+n_{2}-2, \quad 24+26-2=48$, hasil $t_{\text {tabel }}$ pada urutan 48 terlihat angka 1,95. Hal ini berarti thitung lebih lebih besar dari tabel yaitu 2,55>1,95. Kesimpulan yang diperoleh adalah $\mathrm{H}_{0}$ ditolak dan $\mathrm{H}_{\mathrm{a}}$ diterima, yang berarti bahwa Problem Based Learning (PBL) efektif 
terhadap kemampuan berpikir kreatif mahasiswa Program Studi Tadris Matematika.

Uji hipotesis dengan uji-t pada taraf nyata $\alpha=$ 0,05 diperoleh bahwa $t_{\text {hitung }}>t_{\text {tabel }}$ sehingga $\mathrm{H}_{0}$ ditolak dan $\mathrm{H}_{\mathrm{a}}$ diterima. Jadi hipotesis yang berbunyi "Ada pengaruh Problem Based Learning (PBL) terhadap kemampuan berpikir kreatif mahasiswa Program Studi Tadris Matematika" dapat diterima. Hal ini dapat dilihat dari rata-rata kelas eksperimen sebesar 71,54, dan rata-rata kelas kontrol sebesar 63,35. Perbedaan tersebut dapat terjadi karena pada kelas eksperimen digunakan pembelajaran berbasis masalah, yakni pembelajaran yang dimulai dari suatu permasalahan, kemudian mahasiswa diorganisasikan dalam suatu kelompok kecil. Dalam kelompok tersebut, mahasiswa berdiskusi untuk menentukan penyelesaian dari permasalahan dengan memanfaatkan pengetahuan yang dimiliki. Pada tahap inilah kemampuan berpikir kreatif mahasiswa dilatih. Mahasiswa dituntut untuk menyelesaikan masalah tersebut dengan cara yang sesederhana mungkin. Setelah penyelesaian tersebut diperoleh, para mahasiswa diminta untuk menyajikan hasil diskusi mereka dengan mengirimkan satu wakil dari tiap kelompok untuk mempresentasikan hasil diskusi mereka di depan kelas, sehingga dalam proses belajar tampak keaktifan mahasiswa dan pada hasil diskusi terdapat beberapa jawaban yang berbeda dari tiap kelompok. Hal ini menandakan bahwa mahasiswa mempunyai kemampuan untuk berpikir secara kreatif.

Problem Based Learning (PBL) sangat efektif untuk diaplikasikan kepada mahasiswa. Keterampilan untuk memecahkan masalah sangat dibutuhkan karena PBL merupakan hasil dari suatu proses menginvestigasi, pemahaman dan memberikan solusi dari suatu masalah (Subana, 2001). Dengan demikian prinsip utama dari PBL adalah pemecahan masalah yang otentik. Masalah yang dibawa ke dalam kelas merupakan stimulus awal dan kerangka utama proses pembelajaran. Dalam PBL, mahasiswa akan terpacu untuk memecahkan masalah secara efektif, yang nantinya berguna di kehidupan profesionalnya. PBL berangkat dari asumsi bahwa belajar merupakan proses konstruksi pengetahuan secara aktif dan dipengaruhi oleh faktor sosial. Dalam PBL, dosen hanya bertindak sebagai fasilitator, bukan sebagai sumber informasi. Dosen sebagai fasilitator harus dapat membangun motivasi mahasiswa yang secara intrinsik tertarik dengan materi, membagi mahasiswa dalam kelompok kerja dan membantu mahasiswa untuk menjadi pebelajar mandiri. Disini kemampuan mahasiswa berpikir kreatif diukur melalui soal yang dengan kriteria hanya terdapat satu indikator di tiap soal.

\section{SIMPULAN DAN SARAN}

Dari pengujian data di atas didapatkan bahwa, $\mathrm{H}_{\mathrm{a}}$ diterima untuk taraf signifikan 5\% dengan kata lain tidak cukup alasan untuk menerima $\mathrm{H}_{0}$. Jadi hipotesis penelitian yang telah dibuat benar, yaitu ada pengaruh signifikan antara Problem Based Learning terhadap kemampuan berpikir kreatif mahasiswa Program Studi Tadris Matematika. Sebagaimana kriteria pengujian untuk Uji t, yaitu terima $\mathrm{H}_{a}$ jika nilai $t_{\text {hitung }}$ lebih besar dari $t_{\text {tabel. }}$ Karena nilai $t_{\text {hitung }}$ tersebut di atas lebih besar, maka hipotesis nol $\left(\mathrm{H}_{0}\right)$ ditolak dan $\mathrm{H}_{\mathrm{a}}$ diterima. Hasil analisis perlakuan yang berbeda pada kelas eksperimen dan kelas kontrol dapat memberikan pengaruh terhadap kemampuan berpikir kreatif yang dilihat dari hasil belajar mahasiswa. Berdasarkan hasil penelitian dan pembahasan data penelitian yang telah diuraikan sebelumnya, maka dapat diambil kesimpulan bahwa "Problem Based Learning efektif terhadap kemampuan berpikir kreatif mahasiswa Program Studi Tadris Matematika".

Selanjutnya dari hasil penelitian tersebut, peneliti memberikan saran sebagai referensi untuk meningkatkan hasil belajar sebagai berikut.

1. Penggunaan Problem Based Learning dalam proses pembelajaran terhadap kemampuan berpikir kreatif mahasiswa hendaknya tetap memperhatikan karakter materi yang dibahas

2. Dapat digunakan sebagai bahan referensi bagi mahasiswa untuk melakukan penelitian selanjutnya

3. Diharapkan bagi peneliti selanjutnya untuk menambahkan variabel lainnya yang tidak diamati dalam penelitian ini agar dihasilkan kajian yang lebih bervariasi terkait kemampuan berpikir kreatif

\section{UCAPAN TERIMA KASIH}

Peneliti mengucapkan terima kasih yang sebesar-besarnya kepada seluruh civitas akademika UIN Mataram, khususnya Program Studi Tadris Matematika, Fakultas Tarbiyah dan Keguruan yang telah memberikan wadah kepada peneliti untuk mengaplikasikan pengetahuan yang dimiliki. Ucapan terima kasih juga peneliti sampaikan kepada mahasiswa kelas IIIA dan IIIB yang telah bersedia untuk bekerjasama menjadi sampel penelitian kali ini, dan juga kepada keluarga yang selalu memberikan motivasi dan dorongan dalam setiap hal yang peneliti lakukan. 
48 | JTAM, Vol. 1, No. 1, Oktober 2017, Hal. 41-48

\section{REFERENSI}

[1] Evans, James. R. (1991). Berpikir Kreatif, dalam Pengambilan Keputusan dan Manajemen. Jakarta: Bumi Aksara.

[2] Febrianita, Nurzila. (2010). Pengembangan Perangkat Pembelajaran Pokok Bahasan Lingkaran Berbasis Pemecahan Masalah untuk Melatih Kemampuan Berpikir Kreatif Siswa SMP. Tesis Pasca Universitas Sriwijaya Palembang

[3] Iskandar. (2009). Psikologi Pendidikan (Sebuah Orientasi Baru). Cipayung: Gaung Persada (GP) Press.

[4] Munandar, Utami. (2009). Pengembangan Kreativitas Anak Berbakat. Jakarta: PT. Rineka Cipta.

[5] Riyanto, Yatim. (2010). Paradigma Baru Pembelajaran. Jakarta: Kencana Prenada Media Grup.

[6] Rusman. (2010). Seri Manajemen Bermutu ModelModel Pembelajaran Mengembangkan Profesionalisme Guru. Jakarta: PT. Raja Grafindo.

[7] Subana dan Sudrajat. (2001). Dasar-Dasar Penelitian Ilmiah. Bandung: Pustaka Setia.

[8] Sudjana. (2005). Metode Statistika. Bandung: Tarsito.

[9] Sugiyono. (2010). Metode Penelitian Pendidikan. Bandung: Alfabeta.

[10] Suharsimi. (2010). Prosedur Penelitian Suatu Pendekatan Praktik. Jakarta: PT. Rineka Cipta.

[11] Trianto. (2007). Model-Model Pembelajaran Inovatif Berorientasi Kontruktivistik. Jakarta: Prestasi Pustaka. 